DOI: 10.46340/eppd.2020.7.3.5

Oleksandr Grygorov, PhD in Law

ORCID ID: https://orcid.org/0000-0003-4292-8803

Taras Shevchenko National University of Kyiv, Ukraine

\title{
INTERNATIONAL AND REGIONAL STANDARDS IN THE AVIATION SECTOR FOR THE PREVENTION OF "NOISE POLLUTION"
}

\author{
Олександр Григоров, к. ю. н. \\ Київський національний університет імені Тараса Шевченка, Україна

\section{МІЖНАРОДНІ ТА РЕГІОНАЛЬНІ СТАНДАРТИ \\ ІЗ ЗАПОБІГАННЯ «ШУМОВОГО ЗАБРУДНЕННЯ» В АВІАЦІЙНІЙ СФЕРІ}

\begin{abstract}
The article is devoted to the study of the formation and development of special environmental standards in the aviation sector at the universal and regional levels. Since the 1970s, one of the vectors of the International Civil Aviation Organization's (ICAO) environmental policy has been the development of environmental standards aimed at reducing the negative impact of aviation noise on the environment and human health. The main tasks in this area were the reduction of aircraft noise associated with the operation of aircraft (especially aircraft engines) and airport infrastructure.

The most successful example of regional practice to prevent "noise pollution" today is the EU practice. Special EU Directives in this area are aimed at the practical implementation of legal models for reducing the level of airborne noise, improving the planning of airport infrastructure, restricting flights at night, and so on.
\end{abstract}

Keywords: ICAO, EU, aircraft noise certifications, balanced approach, operational limitations.

Шумовий режим території поблизу аеропортів залежить від напрямків злітно-посадкових смуг, інтенсивності польотів впродовж дня, сезонів року, типів повітряних суден, що базуються на даному аеродромі, інших факторів. Разом із відмінностями у правовому регулюванні на рівні держав стосовно шуму від повітряних суден, ці чинники можуть перешкоджати зростанню ролі авіації в економічному розвитку ${ }^{1}$. Природно, що обмеження чи зменшення кількості людей, які страждають від авіаційного шуму, $\epsilon$ одним із головних пріоритетів IКАО, зокрема однією 3 ключових екологічних цілей.

Як стверджує українська дослідниця М.Раскалєй, першим кроком у цьому напрямку стало прийняття в 1969 р. у ході 16 сесії Асамблеї ІКАО в Буенос-Айресі спеціальної резолюції, яка визнала серйозність проблеми шуму в околицях аеропортів і дала вказівку Раді ІКАО розробити міжнародні специфікації та пов'язаний із цим керівний матеріал для контролю за авіаційним шумом. Резолюція містила також вказівку для ІКАО включати до додатків або інших відповідних документів ІКАО описи та методи вимірювання авіаційного шуму та визначати прийнятні обмеження для шумів, створюваних повітряними суднами ${ }^{2}$.

Стандарти та Рекомендована практика (САРП) ІКАО щодо авіаційного шуму були вперше ухвалені Радою ІКАО в 1971 р. відповідно до положень ст. 37 Чиказької конвенції у вигляді Додатка 16 до Конвенції. Подальші зміни зумовлені розвитком технологій, більшим залученням

\footnotetext{
${ }^{1}$ The Balanced Approach to Aircraft Noise Management. International Civil Aviation Organization. $<$ https://www.icao.int/environmental-protection/Documents/Publications/Guidance_BalancedApproach_Noise.pdf $>$ (2020, травень, 25).

2 Раскалей, М. (2016). Экологические аспекты международного воздушного права (часть II). Legea Şi Viata, 57.
} 
громадськості відповідної місцевості до ухвалення рішень, підвищенням уваги до охорони навколишнього середовища ${ }^{1}$.

Чинні норми щодо шуму повітряних суден викладені в Томі I «Авіаційний шум» Додатка 16 про охорону навколишнього середовища до Чиказької конвенції в редакції 2013 p. Передбачена сертифікація повітряних суден щодо шуму та емісії авіаційних двигунів, яку має здійснювати держава, де зареєстроване повітряне судно ${ }^{2}$. Для кожної категорії (класу) повітряних суден норми щодо шуму містяться в окремому розділі Додатка I. Але для основної категорії «Реактивні і гвинтові літаки» при введенні нових обмежень 3'являється нова глава. Так, відповідно до норм Глави 2 можна було сертифікувати літаки по шуму в період 1971-1977 pp. У 1977 р. було введено норми Глави 3 на 10 одиниць ефективного рівня шуму, що сприймається, в децибелах (EPNdB). Вони більш жорсткі, ніж передбачені Главою 2. Відповідно до цього Стандарту літаки проходили сертифікацію до 2006 р., коли була введена Глава 4.

Норми Глави 4 ще на 10 одиниць жорсткіші, але з'явилися і деякі інші нововведення. Якщо раніше нормувалися рівні шуму повітряного судна в кожній з трьох сертифікаційних точок: на розбігу збоку від злітно-посадкової смуги, ЗПС (злітний режим двигунів), на наборі висоти і на посадці, то починаючи з Глави 4, нормується рівень шуму повітряного судна за сумою трьох сертифікаційних точок (так званий кумулятивний рівень), але за умови виконання в кожній з цих трьох точок як мінімум нормативних обмежень Глави $3^{3}$.

У Томі I Додатка 16 містяться Стандарти для гвинтових літаків, вертольотів і конвертопланів, розкрито методи оцінки сертифікації шуму, надано методичні вказівки щодо розрахунку обмежень на шум i шуму допоміжних силових установок, щодо управління документацією 3 шуму та планування землекористування. Нові норми вводять в два етапи: до кінця 2018 р. для літаків зі злітною масою понад 55 тон, а до кінця 2020 р - до 55 тон. Справа в тому, що виконання вимог нового Стандарту більш легкими літаками є складнішим завданням.

Важливо, що у Томі I деталізовано процедури моніторингу шуму, оцінки шуму в аеропортах та застосування так званого «збалансованого підходу до управління шумом». Він відображений у спеціальному Керівництві ІКАО 2008 р. і передбачає виявлення проблем шуму в конкретному аеропорті та аналіз заходів, що вживають для зменшення шуму. Йдеться про чотири основних видів заходів: 1) ослаблення шуму в джерелі; 2) планування та організація землекористування; 3) експлуатаційні прийоми зниження шуму; 4) експлуатаційні обмеження.

Що стосується першого аспекту, то крім Стандартів сертифікації існують і інші способи ослаблення шуму повітряних суден. Однак, як визначено ІКАО в рамках збалансованого підходу, ослаблення шуму в джерелі обмежується ухваленням і впровадженням Стандартів сертифікації по шуму. Інші пов'язані з повітряними суднами заходи, такі як експлуатаційні обмеження і прийоми зниження шуму, належать до різних основних елементів збалансованого підходу.

Планування землекористування полягає в недопущенні несумісного землекористування (наприклад, будівництва житлових будинків і шкіл) поблизу аеропортів і в заохоченні сумісного землекористування (наприклад, промислове i комерційне використання). ІКАО рекомендує державам вживати таких запобіжних заходів, як розміщення нових аеропортів на певній відстані від районів, чутливих до шуму; облік принципів планування землекористування на початковому етапі будівництва будь-якого нового або розширення існуючого аеропорту; визначення та уточнення зон навколо аеропортів, пов'язаних з різними рівнями шуму, зважаючи на чисельність населення, його збільшення, прогнози зростання перевезень; ухвалення законодавства, підготовка рекомендацій або визначення інших прийнятних засобів забезпечення відповідності цим критеріям землекористування; забезпечення надання населенню навколо аеропортів інформації, що стосується польотів повітряних суден та їхніх екологічних наслідків.

До експлуатаційних прийомів належать використання прийнятної за рівнем шуму злітнопосадкової смуги для відхилення повітряних суден на початковій і кінцевій ділянках траєкторії польоту від зон, чутливих до впливу шуму; використання прийнятної за рівнем шуму маршрутів

\footnotetext{
${ }^{1}$ Bartsch, R.I.C. (2016). International Aviation Law: A Practical Guide. Routledge, 126.

2 Яценко, П.С. (2017). От авиационного шума к недобросовестной конкуренции. Право: история, теория, практика: материалы V Международной научной конференции. Санкт Петербург, 138-141.

${ }^{3}$ Халецкий, Ю.Д. (2014). ИКАО: Новый стандарт на шум самолетов гражданской авиации. Двигатель.

Научно-технический журнал, 2 (92), 8.
} 
таким чином, щоб повітряні судна при зльоті і посадці могли уникати чутливих до впливу шуму зон, зокрема шляхом розворотів для відхилення повітряних суден від зон, чутливих до шуму, розташованих під звичайними траєкторіями зльоту і заходу на посадку або безпосередньо прилеглих до них; використання прийомів зниження шуму при зльоті або заході на посадку в цілях оптимізації розподілу шуму на землі при одночасному дотриманні необхідного рівня безпеки польотів.

Нарешті, відповідно до збалансованого підходу експлуатаційне обмеження визначається як «будь-яка дія, пов'язана з шумом, що обмежує або скорочує доступ повітряного судна до будь-якого аеропорту». Може йтися про обмеження чи заборону руху найбільш гучних повітряних суден в аеропорту, дозволяючи тим самим локалізувати або звузити контури шуму навколо аеропорту ${ }^{1}$.

Кінцевими цілями цієї діяльності $\epsilon$, по-перше, розв'язання проблем авіаційного шуму в конкретних аеропортах екологічним та економічно відповідальним способом i, по-друге, досягнення максимальної екологічної вигоди найбільш економічно ефективним способом, при визнанні того, що держави вже мають нормативно-правові акти та політику стосовно авіаційного шуму.

Цих цілей можна досягти шляхом звернення до гнучкого, послідовного та прозорого процесу при оцінці заходів зменшення шуму, включаючи підхід «від аеропорту до аеропорту» (розв'язання проблем, притаманних визначеним аеропортам), використання об'єктивних критеріїв та критеріїв вимірювання, проведення консультацій з усіма зацікавленими сторонами, своєчасного та адекватного повідомлення про ухвалені рішення, розв'язання спорів, поширення та обміну інформації.

Сучасна діяльність та плани IКАО на майбутнє стосуються розвитку технологій скорочення шуму, залучення громад до управління природоохоронною діяльністю у сфері авіації, ухвалення Стандартів шуму надзвукових літаків. Щодо першого Комітет з охорони навколишнього середовища у сфері авіації провів незалежний експертний огляд для оцінки очікуваних рівнів шуму комерційних літаків до 2020 і 2030 pp. $^{2}$ Цей огляд, опублікований у 2014 р., зосереджено на нових літаках і двигунах ${ }^{3}$.

Визнаючи важливість залучення громад до вирішення екологічних проблем, у 2013 р. Комітет взяв на себе завдання систематизувати тематичні дослідження стану аеропортів по всьому світу, а у 2016 р. розробив Циркуляр IКАО про залучення громадськості до екологічного управління авіацією. Циркуляр спрямований на надання допомоги державам та авіаційній промисловості, зокрема аеропортам, авіакомпаніям та постачальникам аеронавігаційних послуг, i залучення місцевих громад на ранніх етапах проектування будівництва аеропортів для розв'язання екологічних проблем ${ }^{4}$.

Що стосується розробки Стандарту для майбутніх надзвукових літаків, то ця робота спрямована на встановлення технічних процедур льотних випробувань для їхньої сертифікації. Передбачається, що сертифікація надзвукового літака може відбутися в період 2020-2025 pp. ${ }^{5}$

За даними СС у державах-членах на самопочуття та здоров'я близько 50 млн. осіб щороку впливає шум, спричинений повітряними суднами ${ }^{6}$. Він $є$ головною причиною негативної реакції громад на роботу та розширення аеропортів, що призводить до обмежень діяльності аеропортів і протидії їхньому будівництву.

Чинні директиви $Є С$ вимагають від держав-членів забезпечити, щоб відповідні види цивільних повітряних суден, зареєстрованих у цих державах, не використовувалися, якщо вони

\footnotetext{
${ }^{1}$ Инструктивный материал по сбалансированному подходу к управлению авиационным шумом. ICAO. Doc 9829, AN/451.<http://aerohelp.ru/sysfiles/374_275.pdf>. (2020, травень, 25).

${ }^{2}$ Environment. Aircraft Noise. International Civil Aviation Organization.

$<$ https://www.icao.int/environmental-protection/Pages/noise.aspx> (2020, травень, 25).

${ }^{3}$ Novel Aircraft-Noise Technology Review and Medium- and Long-Term Noise Reduction Goals. Report by the Second Caep Noise Technology Independent Expert Panel. International Civil Aviation Organization. $<$ https://www.icao.int/publications/Documents/10017_cons_en.pdf $>$ (2020, травень, 25).

${ }^{4}$ Circular 351. Community Engagement for Aviation Environmental Management. International Civil Aviation Organization. $<$ https://www.icao.int/environmental-protection/Documents/COMMUNITY_ENGAGEMENT_ FOR\%20AVIATION\%20ENVIRONMENTAL_\%20MANAGEMENT.EN.pdf>. (2020, травень, 25).

${ }^{5}$ Supersonic Aircraft Noise Standards Development. International Civil Aviation Organization.

$<$ https://www.icao.int/environmental-protection/Pages/Supersonic-Aircraft-Noise-Standards-Development.aspx $>$ (2020, травень, 25).

${ }^{6}$ Kephalopoulos, S., Paviotti, M., Anfosso-Lédée, F. (2012). Common Noise Assessment Methods in Europe. CNOSSOS-EU. <https://ec.europa.eu/jrc/sitecsh/files/cnossos-eu\%2520jrc\%2520reference\%2520report_final_ on\%2520line\%2520version_10\%2520august\%25202012.pdf> (2020, травень, 25).
} 
не сертифіковані відповідно до певних глав Тому 1 Додатка 16 Чиказької конвенції, враховуючи те, що Додаток 16 охоплює лише окремі види повітряних суден. Першою стала Директива № 80/51/СЕС, яка містила заборону використовувати на території держав-членів повітряні судна без сертифіката відповідності шумових показників стандартам Директиви ${ }^{1}$. У практичному сенсі вона запобігла внесенню повітряних суден, несертифікованих щодо рівня шуму, передбаченого Стандартами IКАО, до цивільних авіаційних реєстрів держав-членів. Директива діяла до ухвалення Регламенту № 1592/2002 про спільні правила у сфері цивільної авіації та створення Європейського агентства з авіаційної безпеки ${ }^{2}$.

Чинна донині Директива № 89/629/СЕС про обмеження шумової емісії цивільних дозвукових реактивних літаків зробила стандарти більш жорсткими ${ }^{3}$. 31.11 .1990 р. державам-членам було дозволено вносити до своїх повітряних реєстрів тільки ті літаки, які відповідали вищим Стандартам Глави 3 Тому 1 Додатка 16 Чиказької конвенції стосовно дозвукових реактивних літаків та гвинтових літаків масою 5700 кг. Проте ця директива не передбачала кінцевого терміну припинення експлуатації літаків, що відповідають Стандартам Глави 2 про більш старі дозвукові реактивні літаки.

Директива № 92/14/ЄЕС про обмеження експлуатації літаків заборонила експлуатацію з 1.04 .1995 р. повітряних суден, які не відповідають Стандартам Глави 3. Винятки стосуються повітряних суден, які відповідають Стандартам Глави 2 і яким не виповнилося 25 років. Їх можна було експлуатувати до 1.04 .2002 p.

Інші винятки стосуються авіакомпаній деяких держав, що розвиваються (перелічених в Додатку до Директиви), або до авіакомпаній держав СС, які зможуть довести, що таке обмеження матиме негативний вплив на їхню діяльність ${ }^{4}$. Директива № 2006/93/СС про регулювання експлуатації літаків замінила Директиву № 92/14/СЕС для пристосування до нової редакції Додатка 16 до Чиказької конвенції.

Важливим етапом у регулюванні рівня шуму від діяльності цивільної авіації стало ухвалення Директиви № 2002/49/СС про оцінку та управління шумовим забрудненням. У ній передбачено три види заходів: 1) складання стратегічних мап шумів; 2) розробка та ухвалення планів дій зі скорочення шуму на основі результатів картографування; 3) інформування громадськості про ці заходи 6 . Мапи мали бути складені до 2007 р. для аеропортів, в яких здійснюється понад 50 тис. прильотів і вильотів щороку, та повинні оновлюватись кожні 5 років.

У мапах держави мали відобразити ситуацію з шумом у відповідних районах (у минулому, наразі та за прогнозами на майбутнє); вказати на перевищення граничних показників шуму у випадку, якщо вони існували; зазначити розрахункову кількість житлових будинків, шкіл і лікарень в районі, що піддається впливу шуму, а також розрахункову кількість людей, які знаходяться в зоні, охопленій мапою.

На основі складання стратегічних мап шумів держави-члени повинні були розробити плани дій для управління та, у разі необхідності, скорочення рівня шуму. Втім, автори Директиви № 2002/49/ЄС не регламентували будь-яких обов’язкових граничних значень шуму

\footnotetext{
${ }^{1}$ Краснова, Ю. (2010). Проблеми адаптації національного екологічного законодавства до законодавства Європейського Союзу у сфері забезпечення екологічної безпеки в галузі авіації. Вісник Київського національного університету імені Тараса Шевченка. Юридичні науки, 82, 58.

${ }^{2}$ Regulation (EC) No 1592/2002 of the European Parliament and of the Council of 15 July 2002 on common rules in the field of civil aviation and establishing a European Aviation Safety Agency (Text with EEA relevance). Official Journal, 7.9.2002, 240, 1-21.

${ }^{3}$ Council Directive 89/629/EEC of 4 December 1989 on the limitation of noise emission from civil subsonic jet aeroplanes. Official Journal, 13.12.1989, 363, 27-29.

${ }^{4}$ Council Directive 92/14/EEC of 2 March 1992 on the limitation of the operation of aeroplanes covered by Part II, Chapter 2, Volume 1 of Annex 16 to the Convention on International Civil Aviation, second edition (1988). Official Journal. 23.3.1992. 76. 21-27.

${ }^{5}$ Directive 2006/93/EC of the European Parliament and of the Council of 12 December 2006 on the regulation of the operation of aeroplanes covered by Part II, Chapter 3, Volume 1 of Annex 16 to the Convention on International Civil Aviation, second edition (1988) (codified version) (Text with EEA relevance). Official Journal. 27.12.2006. 374. 1-4.

${ }^{6}$ Directive 2002/49/EC of the European Parliament and of the Council of 25 June 2002 relating to the assessment and management of environmental noise - Declaration by the Commission in the Conciliation Committee on the Directive relating to the assessment and management of environmental noise. Official Journal. 18.7.2002. 189. 12-25.
} 
або необов'язкових цільових значень, перевищення яких вимагало б розробки плану дій. У цьому нормативно-правовому акті розкрито зміст поняття «граничний рівень шуму», але уточнено, що його величина має визначатися державами-членами. Йдеться про «рівень, перевищення якого змушує компетентні органи розглянути або запровадити заходи щодо його скорочення». ${ }^{1}$

Інший важливий акт - Регламент № 925/1999 про реєстрацію та експлуатацію в межах ЄС деяких типів цивільних дозвукових реактивних літаків, які були змінені та повторно зареєстровані як такі, що відповідають Стандартам Тому I Частини II Глави 3 Додатка 16 до Чиказької конвенції. Регламент, спрямований на заборону реєстрації в Європі літаків, оснащених пристроями для зменшення шуму ${ }^{2}$, був скасований Директивою № 2002/30/ЄС. Згідно з останньою держави ЄС були зобов'язані забезпечити, щоб люди, які мешкають поблизу аеропортів, були захищені від надмірного шуму, і вживати відповідні заходи таким чином, щоб не перешкоджати економічному зростанню регіонів або розвитку повітряних перевезень.

Директива встановлює загальні правила управління шумом повітряних суден, правила оцінки потреби в експлуатаційних обмеженнях та правила, які регулюють впровадження таких обмежень, зокрема, у разі необхідності, стосовно повітряних суден, що відповідають лише Стандартам Додатка 16. Міські аеропорти можуть вводити більш жорсткі вимоги, при дотриманні певних критеріїв ${ }^{3}$.

Натомість, нові акти acquis communautaire ЄC вимагають запровадження збалансованого підходу до зменшення шуму, заохочуючи використання тихіших повітряних суден, удосконалення планування землекористування навколо аеродромів, запровадження тихіших засобів функціонування аеропортів i, у крайньому випадку, обмеження польотів уночі ${ }^{4}$.

Йдеться, насамперед, про Регламент № 598/2014 про процедури введення експлуатаційних обмежень на шум, що скасував Директиву № 2002/30/ЄС. Оскільки ці обмеження впливають і на авіаперевізників з держав-нечленів $\mathrm{CC}$, то Регламент відповідає міжнародним принципам управління шумом, так званому «збалансованому підходу», погодженому та рекомендованому ІКАО у Керівництві 2008 р., про яке вже зазначалось. Регламент № 598/2014 встановлює чітку та прозору процедуру запровадження експлуатаційних обмежень таким чином, щоб рішення грунтувалися на фактах та пропонували оптимальні варіанти розв'язання проблем шуму з точки зору безпеки, нарощування інституційного потенціалу та ефективності витрат 5 .

\section{References:}

1. Bartsch, R.I.C. (2016). International Aviation Law: A Practical Guide. Routledge. [in English].

2. Circular 351. Community Engagement for Aviation Environmental Management. International Civil Aviation Organization. $<$ https://www.icao.int/environmental-

protection/Documents/COMMUNITY_ENGAGEMENT_FOR\%20AVIATION\%20ENVIRONMENTAL_\%20M ANAGEMENT.EN.pdf> (2020, May, 25) [in English].

3. Council Directive 89/629/EEC of 4 December 1989 on the limitation of noise emission from civil subsonic jet aeroplanes. Official Journal. 13.12.1989. 363 [in English].

4. Council Directive 92/14/EEC of 2 March 1992 on the limitation of the operation of aeroplanes covered by Part II, Chapter 2, Volume 1 of Annex 16 to the Convention on International Civil Aviation, second edition (1988). Official Journal. 23.3.1992. 76 [in English].

\footnotetext{
${ }^{1}$ Directive 2002/49/EC: historical overview, aims and main features. Noise-reduction action plans. Environmental Noise Directive. $<\mathrm{http} / /$ www.era-comm.eu/Air\%20quality\%20and\%20noise\%20legislation/course/module_3/ 7_action_plans.html> (2020, травень, 25).

${ }^{2}$ Council Regulation (EC) No 925/1999 of 29 April 1999 on the registration and operation within the Community of certain types of civil subsonic jet aeroplanes which have been modified and recertificated as meeting the standards of volume I, Part II, Chapter 3 of Annex 16 to the Convention on International Civil Aviation, third edition (July 1993). Official Journal. 4.5.1999. 115. 1-4.

${ }^{3}$ Directive 2002/30/EC ofeThe European Parliament and of ehe Council of 26 March 2002 on the establishment of rules and procedures with regard to the introduction of noise-related operating restrictions at Community airports (Text with EEA relevance). <https://eur-lex.europa.eu/LexUriServ/LexUriServ.do?uri=OJ:L:2002:085:0040:0046:EN:PDF>. ${ }^{4}$ Spence, T. (2014). New EU rules seen as too timid to reduce airport noise. Euractiv.

$<$ https://www.euractiv.com/section/transport/news/new-eu-rules-seen-as-too-timid-to-reduce-airport-noise/> (2020, травень, 25).

${ }^{5}$ Regulation (EU) No 598/2014 of the European Parliament and of the Council of 16 April 2014 on the establishment of rules and procedures with regard to the introduction of noise-related operating restrictions at Union airports within a Balanced Approach and repealing Directive 2002/30/EC. Official Journal. 12.6.2014. 173. 65-78.
} 
5. Council Regulation (EC) No 925/1999 of 29 April 1999 on the registration and operation within the Community of certain types of civil subsonic jet aeroplanes which have been modified and recertificated as meeting the standards of volume I, Part II, Chapter 3 of Annex 16 to the Convention on International Civil Aviation, third edition (July 1993). Official Journal. 4.5.1999. 115. [in English].

6. Directive 2002/30/EC ofeThe European Parliament and of ehe Council of 26 March 2002 on the establishment of rules and procedures with regard to the introduction of noise-related operating restrictions at Community airports (Text with EEA relevance). $<$ https://eurlex.europa.eu/LexUriServ/LexUriServ.do?uri=OJ:L:2002:085:0040:0046:EN:PDF> (2020, May, 25) [in English].

7. Directive 2002/49/EC of the European Parliament and of the Council of 25 June 2002 relating to the assessment and management of environmental noise - Declaration by the Commission in the Conciliation Committee on the Directive relating to the assessment and management of environmental noise. Official Journal. 18.7.2002. 189. [in English]

8. Directive 2002/49/EC: historical overview, aims and main features. Noise-reduction action plans. Environmental Noise Directive. <http:/www.era-comm.eu/Air\%20quality\%20and\%20noise\%20legislation/course/module_3/ 7_action_plans.html> (2020, May, 25) [in English].

9. Directive 2006/93/EC of the European Parliament and of the Council of 12 December 2006 on the regulation of the operation of aeroplanes covered by Part II, Chapter 3, Volume 1 of Annex 16 to the Convention on International Civil Aviation, second edition (1988) (codified version) (Text with EEA relevance). Official Journal. 27.12.2006. 374 [in English].

10. Environment. Aircraft Noise. International Civil Aviation Organization. $<$ https://www.icao.int/environmentalprotection/Pages/noise.aspx $>$ (2020, May, 25) [in English].

11. Haleckij, Ju.D. (2014). IKAO: Novyj standart na shum samoletov grazhdanskoj aviacii [ICAO: A new standard for the noise of civilian aircraft]. Dvigatel'. Nauchno-tehnicheskij zhurnal [Engine. Scientific and technical journal], no. 2 (92), 8. [in Russian].

12. Instruktivnyj material po sbalansirovannomu podhodu $k$ upravleniju aviacionnym shumom [Guidance material on a balanced approach to aircraft noise management]. ICAO. Doc 9829, AN/451.

$<$ http://aerohelp.ru/sysfiles/374_275.pdf > (2020, May, 25) [in English].

13. Jacenko, P.S. (2017) Ot aviacionnogo shuma k nedobrosovestnoj konkurencii [From aircraft noise to unfair competition]. Pravo: istorija, teorija, praktika: materialy V Mezhdunarodnoj nauchnoj konferencii [Law: history, theory, practice: materials of the V International Scientific Conference]. Saint Petersburg, 138-141. [in Russian].

14. Krasnova, Yu. (2010). Problemy adaptaciyi nacionalnogo ekologichnogo zakonodavstva do zakonodavstva Yevropeiskogo Soyuzu u sferi zabezpechennya ekologichnoyi bezpeky v galuzi aviaciyi [Problems of adaptation of the national ecological legislation to the legislation of the European Union in the field of maintenance of ecological safety in the field of aviation]. Visnyk Kyivskogo nacionalnogo universytetu imeni Tarasa Shevchenka. Yurydychni nauky [Bulletin of Taras Shevchenko National University of Kyiv. Legal sciences], no. 82, 58. [in Ukrainian].

15. Novel Aircraft-Noise Technology Review and Medium- and Long-Term Noise Reduction Goals. Report by the Second Caep Noise Technology Independent Expert Panel. International Civil Aviation Organization. $<$ https://www.icao.int/publications/Documents/10017_cons_en.pdf > (2020, May, 25) [in English].

16. Raskalej, M. (2016). Jekologicheskie aspekty mezhdunarodn̄ogo vozdushnogo prava (chast' II). [Environmental Aspects of International Air Law (Part II)]. Legea Şi Viata, 55-58. [in Russian].

17. Regulation (EC) No 1592/2002 of the European Parliament and of the Council of 15 July 2002 on common rules in the field of civil aviation and establishing a European Aviation Safety Agency (Text with EEA relevance). Official Journal. 7.9.2002. 240 [in English].

18. Regulation (EU) No 598/2014 of the European Parliament and of the Council of 16 April 2014 on the establishment of rules and procedures with regard to the introduction of noise-related operating restrictions at Union airports within a Balanced Approach and repealing Directive 2002/30/EC. Official Journal. 12.6.2014. 173. [in English].

19. Spence, T. (2014). New EU rules seen as too timid to reduce airport noise. Euractiv. <https://www.euractiv.com/ section/transport/news/new-eu-rules-seen-as-too-timid-to-reduce-airport-noise/> (2020, May, 25) [in English].

20. Kephalopoulos, S., Paviotti, M., Anfosso-Lédée, F. (2012). Common Noise Assessment Methods in Europe. CNOSSOS-EU. $<$ https://ec.europa.eu/jrc/sitecsh/files/cnossos-eu\%2520jrc\%2520reference\%2520report final_on\%2520line\%2520version_10\%2520august\%25202012.pdf> (2020, May, 25) [in English].

21. Supersonic Aircraft Noise Standards Development. International Civil Aviation Organization. $<$ https://www.icao.int/environmental-protection/Pages/Supersonic-Aircraft-Noise-Standards-Development.aspx $>$ (2020, May, 25) [in English].

22. The Balanced Approach to Aircraft Noise Management. International Civil Aviation Organization. $<$ https://www.icao.int/environmental-protection/Documents/Publications/Guidance_BalancedApproach_Noise.pdf $>$ (2020, May, 25) [in English]. 